\title{
PERANCANGAN E-LEARNING BERBASIS SCORM CAM STUDY KASUS: FAKULTAS ILMU KOMPUTER UBL
}

\author{
Putri Oriniati ${ }^{1}$ \\ Wiwin Susanty $^{2}$ \\ Program Studi Sistem Informasi \\ Fakultas Ilmu Komputer, \\ Universitas Bandar Lampung \\ Jl. Zainal Abidin Pagar Alam No. 26 \\ Labuhan Ratu Bandar Lampung 35142
}

\begin{abstract}
Universitas Bandar Lampung adalah Perguruan Tinggi Swasta terbesar di Provinsi Lampung yang berdiri sejak tahun 1984 di bawah naungan Yayasan Administrasi Lampung (YAL) yang bergerak dalam bidang pendidikan. Fakultas Ilmu Komputer UBL termasuk salah satu Fakultas yang berperan penting dalam dunia IT. Tujuan dari perancangan ini adalah untuk merancang sebuah website e-Learning Berbasis standar SCORM Content Aggregation Model (CAM) untuk membantu proses belajar mengajar di Fakultas Ilmu Komputer Universitas Bandar lampung. Dengan adanya perancangan ini, diharapkan dapat membantu mahasiswa dan dosen, seperti mudahnya interaktivitas antara sistem pembelajaran dengan sumber belajar. Sehingga tercipta komunikasi dalam proses belajar mengajar. Hasil dari perancangan ini adalah sebuah website e-Learning berbasis SCORM Content Aggregation Model (CAM).
\end{abstract}

Keyword:website,perancangan,e-Learning.

\section{PENDAHULUAN}

Seiring dengan perkembangan tekhnologi informasi (TI) yang semakin pesat, kebutuhan akan suatu konsep dan mekanisme belajar mengajar berbasis TI menjadi tidak terelakan lagi, konsep yang dikenal sebagai e-learning ini membawa pengaruh besar terjadinya proses transformasi pendidikan konvesional kebentuk digital, baik secara isi maupun sistemnya.Elearning adalah suatu kemajuan penting dalam sistem pendidikan modern. Oleh karena itu, metode dan isi e-learning membuat perubahan dan tantangan baru dalam hal teknis dan sosial.Elearning kini banyak dikembangkan dengan menggunakan LMS (Learning Management System).Moodle merupakan salah satu LMS open source yang sangat populer diantara LMS lainnya.Moodle dapat dengan mudah dipakai untuk mengembangkan portal sistem e-learning.Dan Berdasarkan uraian latar belakang diatas penulis mengadakan penelitian dan perancangan dalam penyusunan tugas akhir yang berjudul "PERANCANGAN E-LEARNING BERBASIS SCORM CAM CONTENT AGGREGATION MODEL" (Study Kasus Fakultas Ilmu Komputer UBL).

\section{a. Identifikasi Masalah}

Dari hasil analisa yang dilakukan dalam penyusunan Tugas Akhir terdapat beberapa hal yang menjadi masalah yaitu:
1. Kurangnya interaktivitas antara pengguna dengan sistem pembelajaran

2. Belum adanya platform mobile learning di $e$ learning FIK yang dapat memudahkan proses pembelajaran

3. Proses belajar mengajar masih bersifat konvesional (hanya dapat dilakukan didalam kelas)

\section{b. Rumusan Masalah}

Sistem e-learning yang sudah ada banyak dibangun tanpa memperhitungkan cara pembelajaran secara online yang harus dikemas dan didokumentasikan untuk di impor kedalam LMS. SCORM adalah sebuah standar web based yang mengatur komunikasi antara klient sisi ke lingkungan runtime, oleh karna itu muncul sebuah pertanyaan "Apakah penerapan standar SCORM, khususnya SCORM CAM pada perancangan website e-learning dapat meningkatkan proses pembelajaran secara online?"

\section{c. Batasan Masalah}

1. Penelitian yang dilakukan hanya membahas tentang perancangan e-learning dan penerapanSCORM CAM dengan menggunakan CMS MOODLE 2.6 (Modular Object Oriented Dynamic Learning)

2. E-learning yang dapat diakses diperangkat mobile dapat di download di Playstore (Moodle Mobile) khusus perangkat mobile berbasis android. 


\section{d. Tujuan Penelitian}

Tujuan dari penelitian ini adalah diharapkan dengan adanya e-learning yang telah dirancang berdasarkan SCORM CAM dapat mempermudah kegiatan belajar mengajar antara mahasiswa dan dosen.

\section{TINJAUAN PUSTAKA DAN LANDASAN TEORI \\ a. Tinjauan Pustaka}

Untuk mendukung penelitian ini digunakan beberapa tinjauan pustaka yang diambil dari beberapa jurnal penelitian yang berkaitan dengan judul penelitian ini dan pokok bahasan. E-learning

Beberapa kamus menyamakan arti learning (pembelajaran) dengan aktivitas training (pelatihan) atau education (pendidikan). Rosenberg [2001] mendefinisikan learning, dari konteks bisnis, sebagai proses bagaimana seseorang mendapatkan pengetahuan atau keahlian baru untuk meningkatkan prestasinya.

\section{b. Landasan Teori}

SCORM (Sharable Content Object Reference Model) adalah standar pendistribusian paket $e$ learning yang dapat digunakan untuk menampung berbagai spesifikasi dan standar untuk konten $e$ learning berbasis web dengan mengacu pada interoperability, accesibility, dan reusability Rice (2006).

Tujuan dari SCORM adalah sebuah upaya untuk mulai menyeragamkan pengembangan sistem $e$-Learning berbasiskan teknologi web yang disebut Learning Management Systems (LMS). SCORM menggunakan pendekatan object oriented dan memandang bahwa setiap learning object atau content object sebagai sekumpulan objek yang dapat disatukan untuk membangun suatu sistem yang lebih besar. Metadata dalam SCORM merupakan identitas untuk setiap sumber belajar, dan memudahkan untuk mengidentifikasi isi, kategori, dan pencarian Wang (2007).

Berdasarkan pengamatan dilapangan, banyak penyedia konten e-learning tidak memperhatikan standarisasi pendistribusian konten e-learning. Model pembelajaran e-learning harus memenuhi standarisasi sebagai berikut

1. Accessibility, kemampuan untuk mencari dan mengakses komponen instruksional dari suatu lokasi dan mengirimkannya ke banyak lokasi lain.
2. Adaptability, kemampuan untuk menyesuaikan materi sesuai dengan kebutuhan pribadi dan organisasi.

3. Affordability, kemampuan untuk meningkatkan efisiensi dan produktifitas dengan mengurangi biaya dan waktu yang dibutuhkan dalam pengiriman materi.

4. Durability, kemampuan bertahan dari perkembangan dan perubahan teknologi tanpa banyak mengeluarkan biaya untuk mendesain, mengkonfigurasi serta penyimpanan ulang.

5. Interoperability, kemampuan untuk mengambil komponen-komponen materi yang dikembangkan di suatu lokasi dengan kelengkapan tool atau platformnya dan menggunakannya di tempat lain dengan tool atau platform yang berbeda.

6. Reusability, kemudahan menggabungkan dan menggunakan kembali komponen-komponen materi dalam aplikasi-aplikasi dan kontekskonteks bertingkat. Mackenzie (2004).

\section{1) Content Aggregation Model (CAM)}

Content AggregationModel dapat digunakan untuk membuat aturan pedagogi untuk desainer materi pembelajaran.

Sebuah asset memiliki keterangan mengenai dirinya sendiri dengan menggunakan Asset Metadata.

a) Asset

Asset adalah blok bangunan yang utama dari sebuah learning resource. Asset merupakan representasi elektronik dari media seperti, teks, gambar,suara, obyek penelitian atau bagian data lain yang dapat diolah oleh web client dan ditampilkan ke siswa.

\section{b) Sharable Content Object (SCO)}

Mewakili sekumpulan dari asset dimana didalamnya terdapat sebuah asset yang dapat dilaunch pertama kali dengan memanfaatkan SCORM Run Time Environtment untuk melakukan komunikasi dengan Learning Management System (LMS).SCO adalah bagian terkecil dari sebuah materi pembelajaran yang dapat di-tracking oleh LMS dengan SCORM Run Time Environtment.

\section{2) Content Aggregation}

Content Aggregation adalah sebuah peta (struktur materi) yang dapat digunakan untuk menggabungkan berbagai bahan pembelajaran SCO menjadi satu modul pembelajaran yang utuh. 


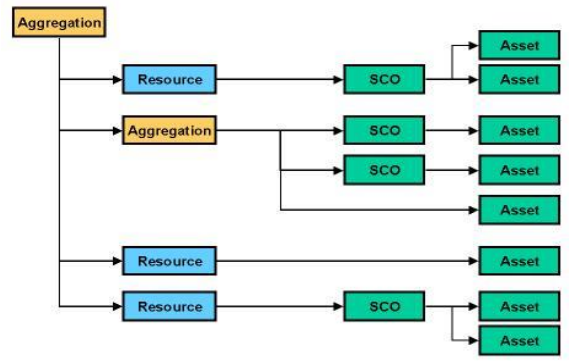

Gambar 2.1 IlustrasiThe SCORM Content Aggregation Model

\section{3) Moodle}

Moodle merupakan singkatan dari Modular Object-Oriented Dynamic Learning Environment yang berarti tempat belajar dinamis dengan menggunakan model berorientasi objek.Dalam penyediannya MOODLE memberikan paket software yang lengkap (MOODLE + Apache + MySQL + PHP).

\section{4) Management Moodle}

Untuk Site ManagementManagement adalah sebagai berikut:

a) Website diatur oleh Admin, yang telah ditetapkan ketika membuat website.

b) Tampilan (Themes) diizinkan pada admin untuk memilih warna,jenis huruf, susunan dan lain sebagainya untuk kebutuhan tampilan.

c) Bentuk kegiatan yang ada dapat ditambah.

d) Source Code. yang digunakan ditulis dengan menggunakan PHP. Mudah untuk dimodifikasi dan sesuai dengan kebutuhan.

Untuk User managementManagement adalah sebagai berikut:

a) Tujuannya ialah untuk mengurangi keterlibatan admin menjadi lebih minimum, ketika menjaga keamanan yang berisiko tinggi.

b) Metode Email standar : Pelajar dapat membuat nama pemakai untuk login. Alamat email akan diperiksa melalui konfirmasi.

c) Tiap orang disarankan cukup 1 pengguna saja untuk seluruh sever. Dan tiap pengguna dapat mempunyai akses yang berbeda.

d) Pengajar mempunyai hak istimewa, sehingga dapat mengubah (memodifikasi) bahan pelajaran. e) Ada "kunci pendaftaran" untuk menjaga akses masuk dari orang yang tidak dikenal

f) Semua Pengguna dapat membuat biografi sendiri, serta menambahkan photo.

g) Setiap pengguna dapat memilih bahasa yang digunakan. Bahasa Indonesia, Inggris, Jerman, Spanyol, Perancis, dan Portugis dll.

Untuk Course managementManagement adalah sebagai berikut:

a) Pengajar mengendalikan secara penuh untuk mengatur pelajaran.

b) Memilih bentuk/metode pelajaran seperti berdasarkan mingguan, berdasarkan topik atau bentuk diskusi.

c) Terdapat Forum, Kuis, Polling, Survey, Tugas, Percakapan dan Pelatihan yang digunakan untuk mendukung proses belajar.

d) Semua kelas-kelas untuk forum, Kuis kuis dan tugas-tugas dapat ditampilkan pada satu halaman (dan dapat didownload sebagai file lembar kerja).

e) Bahan pelajaran dapat dipaketkan dengan menggunakan file zip.

\section{5) CMS (Content Management System)}

Content management system atau yang sering disingkat CMS, adalah perangkat lunak yang memungkinkan seseorang untuk menambahkan dan/atau memanipulasi (mengubah) isi dari suatu situs Web.

\section{6) XАMPP}

XAMPP adalah sebuah software web server apache yang didalamnya sudah tersedia database server mysql dan support php programming. XAMPP merupakan software yang mudah digunakan, gratis dan mendukung instalasi di Linux dan Windows.Keuntungan lainnya adalah cuma menginstal satu kali sudah tersedia Apache Web Server, MySQL Database Server, PHP Support (PHP 4 dan PHP 5) dan beberapa module lainnya. 


\section{MySQL}

MySQL adalah sebuah perangkat lunak pembuat database yang bersifat terbuka atau open source dan berjalan disemua platform baik Linux maupun Windows, MySQL merupakan program pengakses database yang bersifat network sehingga dapat digunakan untuk aplikasi Multi User (Pengguna Banyak).

\section{PHP}

PHP adalah bahasa pemrograman script yang paling banyak dipakai saat ini. PHP banyak dipakai untuk memrogram situs web dinamis, walaupun tidak tertutup kemungkinan digunakan untuk pemakaian lain.Contoh terkenal dari aplikasi PHP adalah phpBB dan MediaWiki (software di belakang Wikipedia).

\section{Unified Modeling Language (UML)}

Sejarah $U M L$ sendiri cukup panjang.Sampai era Tahun 1990 puluhan metodologi permodelan berorientasi objek telah bermunculan di dunia. Diantaranya adalah : metodologi booch, metodologi coad, metodologi OOSE, metodologi OMT, metodologi shlaer-mellor, metodologi wirfsbrock, dsb. Masa itu terkenal dengan masa perang metodologi (method war) dalam pendesainan berorientasi objek.

\section{Pengertian Online}

Online adalah terhubung,terkoneksi, aktif dan siap untuk operasi, dapat berkomunikasi dengan atau dikontrol oleh komputer.

\section{Pengertian World Wide Web}

World Wide Web sering disingkat dengan $w w w$ atau web adalah suatu metode untuk menampilkan informasi di internet, baik berupa teks, gambar, suara maupun video yang interaktif dan mempunyai kelebihan untuk menghubungkan (link) satu dokumen dengan dokumen lainnya (hypertext) yang dapat diakses melalui sebuah browser.

\section{Pemrograman Web}

\section{a) Client Side Scripting}

Client side scripting merupakan suatu bahasa scripting yang aplikasinya langsung diterjemahkan dikomputer client melalui engine khusus yaitu browser web. (Sigit Suyantoro, 2006 : hal.1) b) $H T M L$

Hypertext Markup Language (HTML) adalah bahasa markup yang digunakan untuk membuat sebuah halaman web dan menampilkan berbagai informasi di dalam sebuah browser internet.

\section{c) Java Script}

JavaScript adalah bahasa skrip yang populer di internet dan dapat bekerja di sebagian besar penjelajah web populer seperti Internet Explorer (IE), Mozilla Firefox, Netscape dan Opera. Kode JavaScript dapat disisipkan dalam halaman web menggunakan tagSCRIPT.

\section{d) CSS (Cascading Style Sheets)}

CSS (Cascading Style Sheet) merupakan salah satu bahasa pemrograman web untuk mengendalikan beberapa komponen dalam sebuah web sehingga akan lebih terstruktur dan seragam.

\section{e) Server Side Scripting}

Server side scripting merupakan suatu bahasa scripting yang dalam menerjemahkan scripnya dilakukan di serverweb, kemudian hasilnya baru dikirim ke browserweb dalam bentuk HTML.

\section{Konsep Basis Data}

Database adalah kumpulan dari bermacammacam file yang datanya saling berhubungan atau kumpulan dari data yang terintegrasi, diorganisasikan, disimpan dalam suatu cara yang memudahkan pengambilan kembali.

\section{Perangkat Lunak yang digunakan}

a) Web server Apache

Web Server adalah sebuah perangkat lunak server yang berfungsi menerima permintaan HTTP atau HTTPS dari klien atau browser web dan mengirimkan kembali hasilnya dalam bentuk halaman-halaman web berbentuk dokumen HTML.

b) Database MySQL

MySQL adalah sebuah aplikasi Relational Database Management Server (RDBMS) yang sangat cepat dan kokoh.MySQL sekarang tersedia dibawah izin open source, tetapi juga ada izin untuk penggunaan secara komersial. Keunggulan dari $M y S Q L$ adalah:

1) Bersifat open source. 
Sistem yang digunakan oleh perangkat lunak ini tidak memberatkan kerja dari server, karena dapat bekerja di background.

2) Mempunyai koneksi yang stabil dan kecepatan yang tinggi.

3) Web browser Mozilla Firefox

Mozilla Firefox meruapakan salah satu Web

Browser yang popuer di dunia internet.Mozilla

Firefox dibuat oleh Mozilla Corporation.

\section{Android}

Menurut Teguh Arifianto (2011: 1), android merupakan perangkat bergerak pada sistem operasi untuk telepon seluler yang berbasis linux. Menurut Hermawan (2011 : 1), Android merupakan OS (Operating System) Mobile yang tumbuh ditengah OS lainnya yang berkembang dewasa ini. OS lainnya seperti Windows Mobile, i-Phone OS, Symbian, dan masih banyak lagi.Akan tetapi, OS yang ada ini berjalan dengan memprioritaskan aplikasi inti yang dibangun sendiri tanpa melihat potensi yang cukup besar dari aplikasi pihak ketiga.

\section{Moodle Mobile}

Moodle Mobile adalah sebuah cross-platform aplikasi Moodle.App Moodle Ponsel adalah klien berbasis HTML5 yang menghubungkan ke server Moodle diinstal.Aplikasi ini jugadapat mengambilgaya kustomAnda darisitusMoodleAnda. Karena aplikasiiniadalah aplikasiHTML5, Anda dapat menerapkanaman setiapCSS, CSS2danCSS3gaya. DalaminstalasiMoodleAndapergi

kePlugins/layanan Web/Mobile danmasukkandalam bidangmobile css urlURL yang validmenunjukke fileCSSyang berisigaya kustomAnda.

\section{Big Blue Button}

BigBlueButton adalah sebuah open source
web conference project sistem yang memungkinkan perusahaan dan perguruan tinggi untuk memberikan materi tentang rapat, atau materi pembelajaran yang berkualitas tinggi kepada karyawan atau mahasiswa secara online atau jarak jauh.

\section{METODELOGI PENELITIAN}

Metode Penelitian adalah cara ilmiah untuk mendapatkan data dengan tujuan dan kegunaan tertentu. Metode penelitian yang digunakan dalam penelitian ini menggunakan standar SCORM CAM. SCORM CAM adalah satu set standar teknis yang dikembangkan untuk produk perangkat lunak e-learning memungkinkan interoperabilitas antara produk software e-learning .

\section{a. Metode Pengumpulan Data}

Metode pengumpulan data yang digunakan pada penelitian ini, yaitu :

\section{1) Observasi}

Observasiadalah kemampuan seseorang untuk menggunakan pengamatannya melalui hasil kerja pancaindra mata serta dibantu dengan pancaindra lainnya. Menurut Patton (dalam Poerwandari 1998) tujuan observasi adalah mendeskripsikan setting yang dipelajari, aktivitasaktivitas yang berlangsung, orang-orang yang terlibat dalam aktivitas, dan makna kejadian di lihat dari perspektif mereka yang terlihat dalam kejadian yang diamati tersebut.

\section{2) Studi Pustaka (Library Research)}

Studi pustaka merupakan kegiatan mengumpulkan data-data berupa teori pendukung dari sistem yang dibuat untuk memaparkan tentang teori tersebut berupa data karakteristik. Sumbersumber yang didapat berupa literatur, ebook, dan lainnya yang relevan dengan penelitian.

\section{3) Kuisioner \\ Kuisioner merupakan teknik pengumpulan} informasi yang memungkinkan analisis dan dapat menjadi tolok ukur dalam suatu organisasi tertentu.Dalam mengumpulkan informasi penulis menyebarkan beberapa kuisioner kepada mahasiswa dan dosen sebagai sample pengguna $e$ learning.

\section{b. Analisis Sistem yang berjalan}

Data dari hasil observasi yang dilakukan pada $e$-learning FIK UBL diketahui bahwa sistem $e$ learning saat ini belum menerapkan pembelajaran online sesuai standar SCORM CAM. 


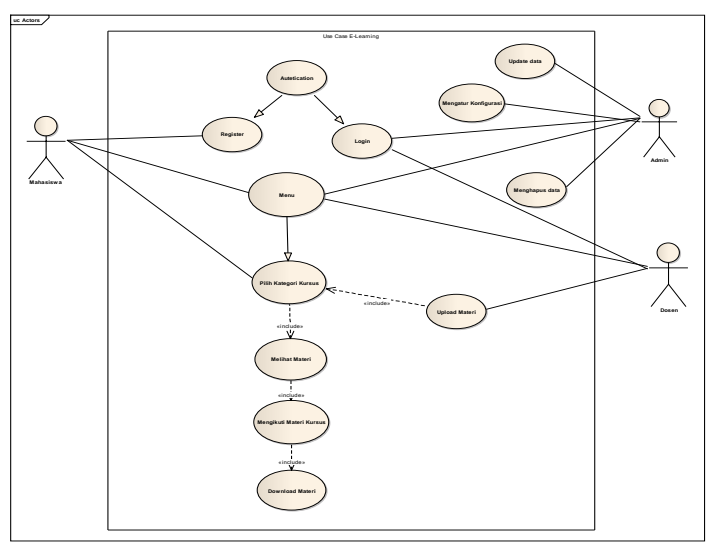

Gambar 3.1 Use Case Diagram (e-learning FIK UBL)

\section{c. Analisa Kebutuhan}

Analisa kebutuhan diperlukan dalam rangka menganalisis kebutuhan-kebutuhan dalam perancangan sebuah sistem maupun pembuatan program aplikasi. Setelah proses analisa kebutuhan dilakukan dengan benar maka kebutuhan sistem dapat diketahui dengan tepat. Selama ini sistem $e$ learning yang sudah ada belum sepenuhnya berjalan dengan tepat, banyak konten-konten $e$ learning, interopabilitas dan interaktivitas antara pengguna dengan sistem pembelajaran yang perlu diterapkan.

\section{1) UML Diagram}

Pemodelan dalam sistem informasi ini menggunakan UML. Tipediagram UML yang akan digunakan dalam pengembangan sistem informasi ini adalah use case (user berinteraksi dengan sebuah sistem), activity diagram (perilaku prosedural dan paralel). Diagram yang dibentuk sebagai berikut :

\section{a) Use Case Diagram}

Use case diagram bersifat statis, diagram ini memperlihatkan himpunan use case dan aktoraktor (suatu jenis khusus dari kelas), yang sangat penting untuk mengorganisasi dan memodelkan perilaku dari suatu sistem yang dibutuhkan serta diharapkan pengguna (Adi Nugroho, 2005: hal.19).

\section{b) Activity Diagram}

Activity diagram merupakan suatu bentuk flow diagram yang memodelkan alur kerja (workflow) sebuah proses system informasi dan sebuah urutan aktifitas sebuah proses. Diagram ini sangat mirip dengan sebuah flowchart karena kita dapat memodelkan sebuah alur kerja dari sebuah aktifitas lainnya atau dari suatu aktifitas kedalam keadaan sesaat.

c) Sequence Diagram

Sequence diagram menggambarkan interaksi antar object pada suatu aplikasi yang dikembangkan .sequence diagram memiliki dua dimensi yaitu dimensi vertikal yang mengambarkan waktu nyang terkait oleh objek.

d) Class diagram

Class diagram membantu kita dalam visualisasi struktur kelas-kelas darisuatusystem dan merupakan tipe diagram yang paling banyak dipakai.Class diagram memperlihatkan hubungan antar kelas dan penjelasan detail tiap-tiap kelas didalam model desain dari suatu system.

\section{Kebutuhan Non-Fungsional}

Analisis kebutuhan non-fungsional dilakukan untuk mengetahui spesifikasi kebutuhan untuk sistem.Spesifikasi kebutuhan melibatkan analisis perangkat keras (hardware), analisis perangkat lunak (software), analisis pengguna (user).

a) Analisis Kebutuhan Perangkat Keras (Hardware)

Untuk menggunakan website $e$ learningdiperlukan beberapa kebutuhan perangkat keras (hardware). Adapun kebutuhan perangkat keras (hardware) sistem tersebut adalah sebagai berikut :

\begin{tabular}{|l|l|l|}
\hline NO & KEBUTUHAN & KETERANGAN \\
\hline 1. & Sistem Operasi & $\begin{array}{l}\text { XP Profesional atau } \\
\text { sesudahnya }\end{array}$ \\
\hline 2. & Prosesor & $\begin{array}{l}\text { Intel Pentium III 2.0 } \\
\text { GHz atau selebihnya }\end{array}$ \\
\hline 3. & Memory & 1 GB atau selebihnya \\
\hline 4. & Ruang Hardisk & Minimal 1 GB \\
\hline 5. & $\begin{array}{c}\text { Monitor } \\
\text { 6. }\end{array}$ & $\begin{array}{c}\text { Keyboard } \\
\text { Mouse }\end{array}$ \\
\hline \multicolumn{2}{|c|}{ Standar 14" } \\
\hline
\end{tabular}

Tabel 3.1 Kebutuhan perangkat keras (hardware)

b) Analisis Kebutuhan Perangkat Lunak (Software)

Keberadaan perangkat lunak sangatlah penting karena perangkat lunak (Software)merupakan suatu alat yang kita gunakan dalam pembuatan sebuah sistem.namun perangkat lunak (Software)tidak dapat berdiri sendiri tanpa adanya perangkat keras (Hardware), karena 
keduanya tidak dapat berfungsi sendiri-sendiri. Maka pada penelitian ini penulis menggunakan beberapa perangkat lunak (Software)seperti :

1. Moodle 2.6

2. $\mathrm{Mdl} 2$

3. Google Chrome/Mozila firefox

4. Perancangan UML menggunakan Enterprise Architect 7.0

5. iSpring, JCLic, Quiz Qreator

6. BigBlueButton

c) Analisis Kebutuhan Pengguna (User)

Pengguna dari perangkat lunak yang akan dibangun ini terdiri dari Administrator, Dosen dan mahasiswa yang memiliki hak akses yang berbeda. Pada penelitian ini, kebutuhan terhadap penggunaakan dipaparkan sebagai berikut :

\section{Admin}

Admin merupakan aktor yang memiliki peran penting dalam penggunaan sistem e-learning. Tugas utama dari admin adalah mengontrol aktivitas dadan mengatur konfigurasi dari sistem e-learning.

2. Dosen

Dosen adalah aktor yang berperan tidak kalah pentingnya dengan seorang admin. Dalam hal ini dosen memiliki peran untuk mempublikasikan hasil penelitiannya.

3. Mahasiswa

Dalam memenuhi kebutuhan akan informasi yang menunjang perkuliahan, peran dari aktor yang disebut mahasiswa adalah untuk memperoleh materi pembelajaran yang dapat didownload dari aplikasi e-learning ini.

\section{d. Variabel Penelitian}

Variabel penelitian yang digunakan dalam perancangan terhadap website e-Learning dengan menggunakan standar SCORM CAM yang terdiri dari kategori-kategori sebagai berikut:

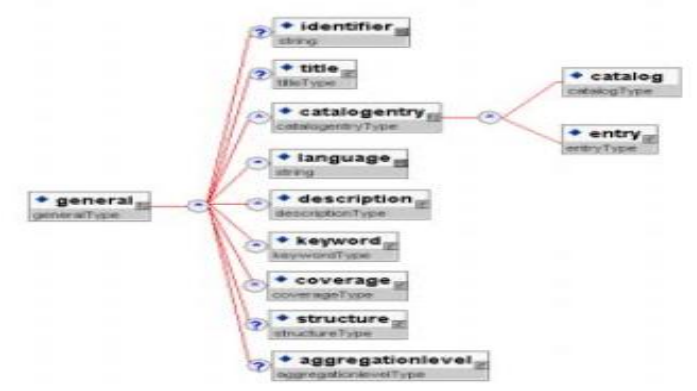

Gambar 3.2Gambar Kategori General (Umum) SCORM CAM

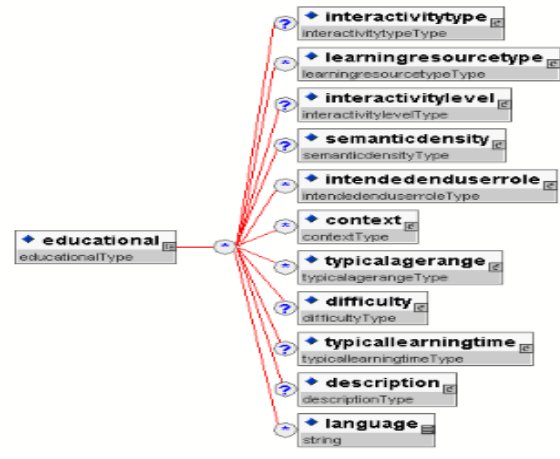

Gambar 3.3Gambar Kategori Educational (Umum) SCORM CAM

\section{e. Tampilan rancanganInterface}

Antarmuka pemakai (User Interface) merupakan mekanisme komunikasi antara pengguna (user) dengan sistem.User Interface dapat menerima informasi dari pengguna dan memberikan informasi kepada pengguna untuk membantu mengarahkan alur penelusuran masalah sampai ditemukan suatu solusi.

1) Beranda (Halaman Utama)

Halaman ini merupakan halaman awal yang dapat diakses oleh pengguna (Admin, Mahasiswa dan Dosen).Pada halaman ini terdapat menu login untuk dapat menggunakan website e-learning baik menggunakankomputerataupun perangkat mobile.

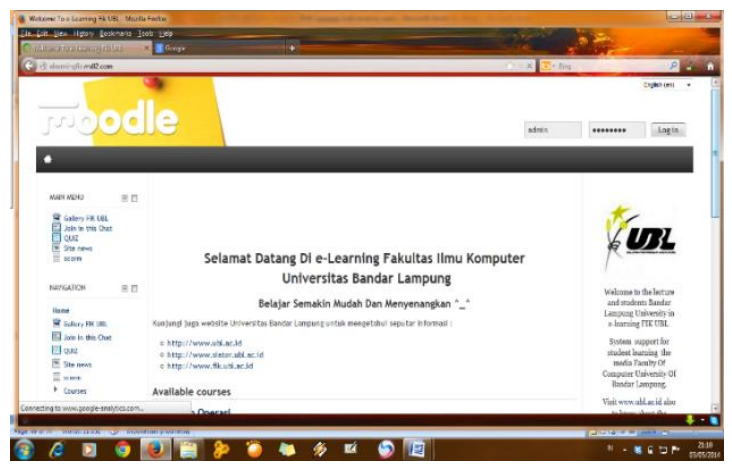

Gambar 3.4Gambar Beranda (Halaman Utama)

2) Halaman Login

Halaman ini berisi form untuk melakukan login dalam mengakses e-learning Username dan password yang valid akan dilanjutkan ke beranda pengguna yang telah terdaftar sebelumnya. 


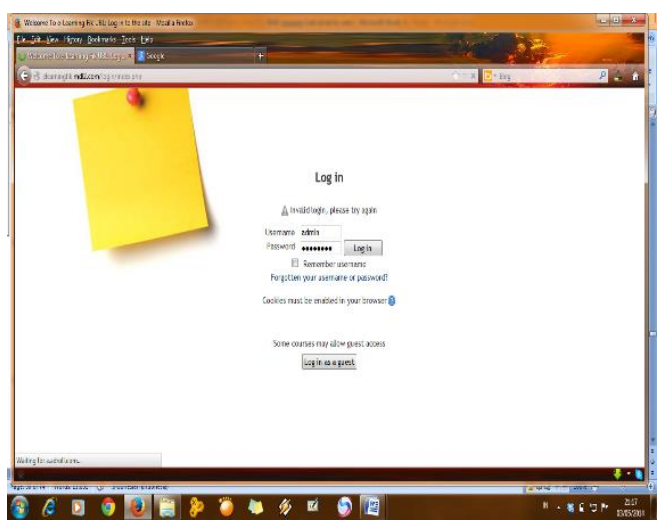

Gambar 3.5Tampilan Halaman Login

\section{3) Halaman Courses}

Halaman ini berisi Mata Kuliah dan materimateri yang dapat diikuti dan didownload oleh mahasiswa.

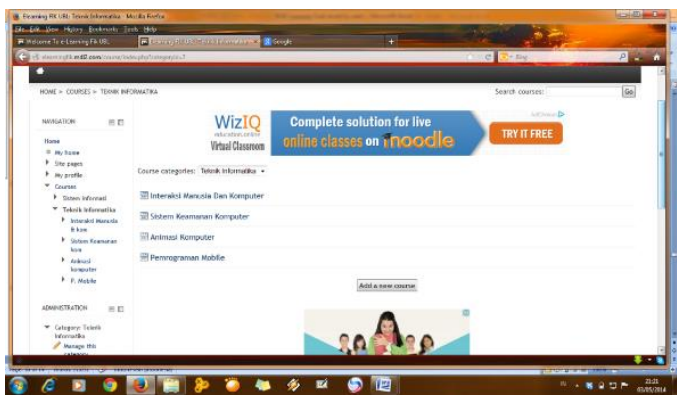

Gambar 3.6Tampilan courses Tekhnik informatika

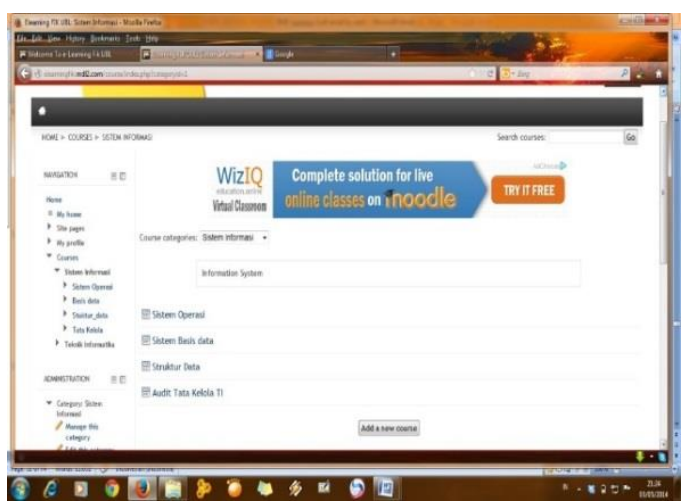

Gambar 3.7Tampilan courses Sistem informatika

\section{HASIL DAN PEMBAHASAN}
a. Sejarah Singkat Fakultas Ilmu Komputer UBL

\section{1) Sejarah Singkat UBL}

Universitas Bandar Lampung berdiri sejak tahun 1984 di bawah naungan Yayasan Administrasi Lampung (YAL), yang pada waktu itu diketuai oleh Bapak Drs.RM.Barusman.

Yayasan Administrasi Lampung adalah sebuah yayasan yang bergerak dalam bidang pendidikan, yang pada tahun 1972 juga mendirikan Akademi Administrasi Niaga (AAN) Tanjungkarang.Kemudian dalam perkembangan namanya berubah menjadi Akademi Sekertariat dan Manajemen (ASM) Bandar Lampung.

\section{2) Visi dan Misi UBL}

Visi atau cara pandang ke depan Universitas Bandar Lampung adalah : "Untuk menjadi Center of Excellence untuk Pengembangan Sumber Daya ManusiaBerkualitas"Untuk mencapai visi tersebut, beberapa kegiatan utama harus dinyatakan sebagai misi. Misi UBL adalah:

a. Mengembangkan program pendidikan tinggi terbaik untuk mengembangkan sumber daya manusia yang berkualitas.

b. Berkontribusi untuk kemajuan ilmu pengetahuan dan teknologi dan pengembangan masyarakat.

\section{(sumber:http://ubl.ac.id/profil/visi-} misi.html )

\section{3) Sejarah Singkat Fakultas Ilmu Komputer (FIK)}

Fakultas Ilmu Komputer Universitas Bandar Lampung merupakan salah satu fakultas yang ada di Universitas Bandar Lampung.Fakultas Ilmu Komputer Universitas Bandar Lampung diresmikan pada tanggal 01 Juni 2000.Pada saat ini Fakultas Ilmu Komputer Universitas Bandar Lampung mempunyai 2 (dua) program studi, yaitu program studi Sistem Informasi (SI) dan program studi Teknik Informatika (TI).

\section{4) Visi Dan Misi Fakultas Ilmu Komputer}

Visi atau cara pandang ke depan Fakultas Ilmu Komputer Universitas Bandar Lampung adalah sebagai berikut:"Pada Tahun 2015 Menjadi Fakultas yang unggul dan menjadi solusi bagi masyarakat melalui proses pendidikan, penelitian dan pengabdian serta menanamkan jiwa technopreneurpada lulusan. 
Untuk mencapai visi tersebut, beberapa kegiatan utama harus dinyatakan sebagai misi. Misi FIK-UBL adalah:

a. Mengembangkan semua program studi agar mampu menyelenggarakan Pendidikan berbasis Kompetensi sesuai dengan Keilmuan dan Dinamika kebutuhan Stakeholder.

b. Meningkatkan fasilitas yang akan digunakan oleh setiap program studi dalam rangka kegiatan pengabdian kepada masyarakat.

c. Melaksanakan kerjasama secara Institutional dengan berbagai lembaga lokal, nasional maupun internasional untuk pengembangan dan pemberdayaan Fakultas.

d. Menjadikan FIK-UBL sebagai pusat layanan penelitian, pelatihan, konsultasi, dan jasa dalam bidang keilmuan teknologi informasi dan terapannya.(sumber : Borang Fakultas Ilmu Komputer Universitas Bandar Lampung)

\section{5) Struktur Organisasi}

Berikut struktur organisasi dari Fakultas Ilmu Komputer Universitas Bandar Lampung :

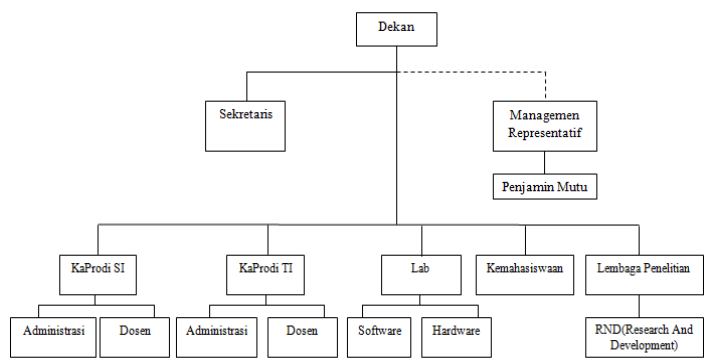

Gambar 4.1 Struktur Organisasi Fakultas Ilmu Komputer

\section{6) Deskripsi Tugas}

Berikut ini adalah deskripsi tugas dari bagan Struktur organisasi Fakultas Ilmu Komputer Universitas Bandar lampung.

a. Dekan

Penanggung jawab utama Fakultas memimpin pelaksanakan dan penyelenggaraan pendidikan, penelitian, dan pengabdian masyarakat, membina tenaga kependidikan, mahasiswa, tenaga administratif fakultas serta membina kerjasama.

b. Sekretaris

Membantu Dekan dalam penyelenggaraan dan pelaksanaan kebijakan dibidang pengembangan akademik, pengembangan profesi, pengembangan penelitian, pengabdian masyarakat, administrasi umum, tata laksana dan pengelolaan keuangan, pengembangan kemahasiswaan dan alumni, dan pengembangan kelembagaan.

c. Ketua Program Studi

Ketua Program Studi (KaProDi) sebagai unit pelaksana akademik yang membantu Dekan dalam pelaksanaa, penyelenggaran dan pengembangan pendidikan akademik dan atau profesional.

Tugas KaProDi adalah berhubungan dan menghadapi berbagai macam orang, seperti dosen, pegawai.

d. Administrasi Pogram Studi

Administrasi program studi mempunyai tugas pokok melaksanakan administrasi pendidikan dan pengajaran, penelitian dan pengabdian kepada masyarakat, kemahasiswaan dan alumni, kepegawaian, keuangan, perlengkapan, dan administrasi umum.

e. Dosen

Dosen adalah pendidik profesional dan ilmuwan dengan tugas utama mentransformasikan, mengembangkan, dan menyebarluaskan ilmu pengetahuan, teknologi, dan seni melalui pendidikan, penelitian, dan pengabdian kepada masyarakat.

f. Kemahasiswaan

Merencanakan, mengkoordinir serta memfasilitasi program-program kemahasiswaan dan alumni sehingga dapat menunjang pelaksanaan Tridharma Perguruan Tinggi.

g. Lembaga Penelitian

Mempersiapkan kegiatan penelitian internal (skripsi, penelitian dosen) dan eksternal (DIKTI maupun institusi swasta).Membangun kerjasama dan mengkoordinasikan kegiatan kerjasama penelitian dengan institusi luar UBL.

h. Manajemen Representatif

Memberi pelatihan kepada staf-staf/pemilik prosedur untuk dapat terus memelihara sistem manajemen yang sesuai dengan standar ISO 9001:2008.Meninjau prosedur-prosedur untuk mengubah agar tercapai efisiensi dan efektifitas kerja.

i. Laboratorium Komputer

Menyediakan ruang kegiatan dan program pengembangan laboratorium software dan hardware.

\section{KESIMPULAN DAN SARAN a. Kesimpulan}

Berdasarkan hasil penelitian dan pembahasan, yang dilakukan mulai dari tahap perancangan hingga pengujian terhadap sistem e-learning, maka kesimpulan yang dapat diambil dari penelitian ini adalah sebagai berikut :

1. Dari hasil analisis dan perancangan yang telah dibuat, pada sistem e-learning berbasis SCORM CAM telah memenuhi standar SCORM CAM.

2. Dari hasil perbandingan Pre Test dan Post Test yang membandingkan tingkat pengaruh antara sistem e-learning FIK dan perancangan 
e-learning berbasis SCORM CAM yang diukur dengan menggunakan sudut penggunaan terhadap user yaitu mahasiswa dan dosen ini meningkat dari segi interactivity dengan sumber belajar.

b. Saran

Adapun saran-saran yang dapat disampaikan oleh penulis adalah:

1. Dengan melihat hasil penelitian dan perancangan ini hendaknya website $e$-learning versi mobile learning di FIK UBL segera diperbaiki dan dimanfaatkan dengan sebaik mungkin guna untuk menunjang proses belajar mengajar mahasiswa dan dosen sesuai dengan standar SCORM CAM.

2. Untuk kontent-konten dan kategori-kategori dalame-Learning versi mobile learning sebaik nya diterapkan sesuai dengan standar SCORM agar menjadi lebih baik lagi dalam kualitas penggunaan dalam pembelajaran.

\section{DAFTAR PUSTAKA}

1. Effendi, Empy, SE., MBA, dan Hartono Zhuang, ST., MBA. 2008. e-Learning Konsep dan Aplikasi. Yogyakarta: Andi.

2. Satria Wahono, Romi. 2003. Pengantar eLearning dan Pengembangannya. http://www.ilmukomputer.com//.

3. Koran, Jaya Kumar C. 2001.Aplikasi Elearning dalam Pengajaran dan Pembelajaran di Sekolah-Sekolah Malaysia.

4. Rahardja, B. 2001.Internet untuk Pendidikan.http://budi.insan.co.id/internet -pendidikan.doc.

5. Sharable Content Object Reference Model (SCORM) version 1.2 : 2001, ADL http://www.adlnet.org//

6. Jogiyanto H.M., Analisa dan Desain, Andi Offset, Yogyakarta, 1995.

7. Booch, Grady, Jacobson, Ivan and Rumbaugh, James. (1998). The Unified Modeling Language Reference Manual. United States of America.

8. Anonymous. 2009 Balanced Scorecard. http://www.balancedscorecard.org//

9. Turban, E, 1995, Decision Support System and Intelligence System:Fourth Edition, Prentice Hall

10. Race, W.H., \& Nash S.S. (2010).Moodle 1.9 teaching techniques: Creative ways to build powerful and affective online course.

11. Birmingham: PACKT Publishing. Herman Wibowo (Penterjemah). 1993. Analisa Laporan Keuangan. Jakarta: PT. Erlangga 